УдК 616.311.2+616.314.17+616.314.19) - $002-036-06: 616.1 / .4$

DOI

(С). І. Бойцанюк, М. С. Залізняк, Н. В. Чорній, Н. В. Манащук, А. В. Чорній

ДВН3 «Тернопільський державний медичний університет імені І. Я. Горбачевського»

\title{
Особливості клінічного перебігу захворювань пародонта у хворих із різною супутньою патологією
}

Резюме. У статті проведено порівняльну оцінку поширення, діагностичної структури, особливостей клінічного перебігу захворювань пародонта на тлі опікової хвороби, остеоартрозу, хронічних коліту та панкреатиту.

Ключові слова: захворювання пародонта, опікова хвороба, остеоартроз, хронічні коліт, панкреатит.

\author{
С. И. Бойцанюк, М. С. Зализняк, Н. В. Чорний, Н. В. Манащук, А. В. Чорний
}

ГВУЗ «Тернопольский государственный медицинский университет имени И. Я. Горбачевского»

\section{Особенности клинического течения заболеваний пародонта у больных с различной сопутствующей патологией}

Резюме. В статье проведена сравнительная оценка распространенности, диагностической структуры, особенностей клинического течения заболеваний пародонта на фоне ожоговой болезни, остеоартроза, хронических колита и панкреатита.

Ключевые слова: заболевания пародонта, ожоговая болезнь, остеоартроз, хронические колит, панкреатит.

\section{S. I. Boytsanyuk, M. S. Zaliznyak, N. V. Chorniy, N. V. Manashchuk, A. V. Chorniy} I. Horbachevsky Ternopil State Medical University

\section{Peculiarities of clinical course of periodontal diseases in patients with various comorbidities}

Summary. This article provides a comparative analysis of the prevalence, diagnostical patterns, clinical course of periodontal diseases on the background of burn disease, osteoarthritis, ulcerative colitis and pancreatitis.

Key words: periodontal disease, burn disease, osteoarthritis, ulcerative colitis, chronic pancreatitis.

Вступ. Значне розповсюдження захворювань пародонта призвело до того, що вони стали пріоритетною проблемою у сучасній стоматології [4].

У численних дослідженнях виявлено тісний взаємозв’язок між загальними захворюваннями організму і хворобами пародонта [3, 7].

Результати вивчення захворювань пародонта привели до узагальненого висновку, що на стан тканин пародонта впливають загальносоматичні захворювання, зміни стану організму, при яких наявні запальний процес, оксидативний стрес, імунологічні розлади, порушення метаболізму кісткової тканини $[3,10]$. Вивчення взаємозв'язків уражень тканин пародонта із захворюваннями внутрішніх органів і систем організму, наявною супутньою патологією дозволяє скласти більш чітку уяву про сутність генезу захворювання і розробити патогенетично спрямовані лікувальнопрофілактичні заходи.

Метою дослідження було провести порівняльну оцінку поширення, діагностичної структури та особливостей перебігу захворю- 
вань пародонта у хворих на остеоартроз, опікову хворобу, хронічні панкреатит та коліт.

матеріали і методи. Для вирішення поставленої мети проведено стоматологічне обстеження та визначення пародонтального статусу в 103 пацієнтів з опіковою хворобою (OX), які перебували на стаціонарному лікуванні у відділенні опікової травми та пластичної хірургії Тернопільської міської комунальної лікарні швидкої допомоги, 102 хворих на хронічний панкреатит (ХП) та 73 пацієнтів із хронічним колітом (ХК), пацієнтів гастроентерологічних відділень лікарень м. Тернополя, 308 хворих з первинним остеоартрозом (ОА) великих суглобів, які лікувалися у реабілітаційносанаторних закладах Тернопільської області.

Обстеження усіх пацієнтів проводили 3 дотриманням загальномедичної послідовності й використанням об'єктивних оцінок стану гігієни порожнини рота і зубоутримувальних тканин. Поширення запального процесу в яснах визначали за пробою ШиллераПисарєва (1956) та з обчисленням папілярномаргінально-альвеолярного індексу (PMA), а характер та ступінь кровоточивості ясен шляхом зондування гудзиковим зондом [11].

Для об’єктивної оцінки стану тканин пародонта використовували комплексний пародонтальний індекс (КПІ за П. А. Леусом, 1987), глибину пародонтальних кишень (ГПК) вимірювали пародонтальним зондом [11]. Стан гігієни порожнини рота визначали за допомогою гігієнічного індексу (ГІ) Федорова-Володкіної (1970) та Гріна-Вермільйона (OHI-S) [111]. Діагноз захворювань пародонта в обстежених встановлювали згідно з класифікацією М. В. Данилевського (1994) [11].

Результати досліджень та їх обговорення. Згідно з проведеними дослідженнями, встановлено значну поширеність захворювань пародонта у групах спостереження, зокрема захворювання пародонта у пацієнтів з опіковою хворобою діагностовано у 92, що становило 89,32 \%, хворих на остеоартроз було у 297 осіб, що відповідало 96,43%, 62 пацієнтів із хронічним колітом, що становило 84,93 \%, 77 хворих на хронічний панкреатит, що склало $75,49 \%$ (рис. 1 ).

Проведений аналіз структури захворювань пародонта показав, що у пацієнтів з опіковою хворобою найбільш розповсюдженим ураженням пародонта був генералізований пародонтит, який виявлено у 70 обстежених (67,9%).
У 22 обстежених (21,4 \%) було діагностовано гінгівіт, з них у 20 осіб (19,4 \%) - катаральний, у 2 (1,9 \%) - гіпертрофічний. Хронічний перебіг генералізованого пародонтиту виявлено у 26 обстежених (25,3%), загострений - у 44 (42,7 \%). Клінічно здорові тканини пародонта були лише в 11 (10,7 \%) хворих.

Аналіз структури захворювань пародонта у хворих на ОА показав значне поширення більш тяжких уражень тканин пародонта. Зокрема, у діагностичній структурі не виявлено запальних захворювань пародонта (гінгівіту), проте простежено високу поширеність генералізованого пародонтиту в 267 хворих (86,7 \%) 3 такою структурою захворювання: ГП початкового - І ступеня - 42 хворих ( 13,6 \%), ГП II ступеня - 115 осіб ( 37,3 \%) і ГП II-III ступенів - 110 хворих (35,7 \%). У 9 осіб (2,9 \%) цієї групи спостерігали локалізований пародонтит, а в 21 особи (6,8 \%) - пародонтоз. Клінічно здорові тканини пародонта діагностували лише в 11 осіб (3,6 \%).

У пацієнтів із хронічними колітами захворювання пародонта були представлені в основному хронічним катаральним гінгівітом (у 46 обстежених із 73, що склало 63,0 \%) та генераізованим пародонтитом (у 16 обстежених із 73, що становило 21,9 \%). Катаральний гінгівіт першого ступеня тяжкості діагностували у 21 хворого (28,8 \%), II ступеня тяжкості у 24 осіб (32,9 \%), III ступеня тяжкості - в 1 пацієнта (1,4%). Проводячи аналіз генералізованого пародонтиту за ступенями тяжкості у пацієнтів із хронічними колітами, в 1 (1,37 \%) діагностовано генералізований пародонтит початкового ступеня, у 14 осіб генералізований пародонтит І ступеня тяжкості, що склало $(19,2 \%)$, та в 1 (1,4\%) хворого - генералізований пародонтит II ступеня тяжкості. При цьому, в усіх пацієнтів реєстрували загострення процесу. Клінічно здорові тканини пародонта виявлено в 11 осіб, що відповідає 15,1 \%.

Серед 102 хворих на хронічний панкреатит виявлено хронічний генералізований катаральний гінгівіт у 56 хворих (54,9 \%) та хронічний генералізований пародонтит у 21 (20,6 \%), які під час огляду були в стадії загострення. Катаральний гінгівіт I ступеня тяжкості було діагностовано у 82,1 \% хворих, катаральний гінгівіт II ступеня тяжкості 17,9 \%, хронічний генералізований пародонтит I ступеня тяжкості спостерігали в 71,4 \% хворих, II ступеня тяжкості - у 28,6 \% осіб. 


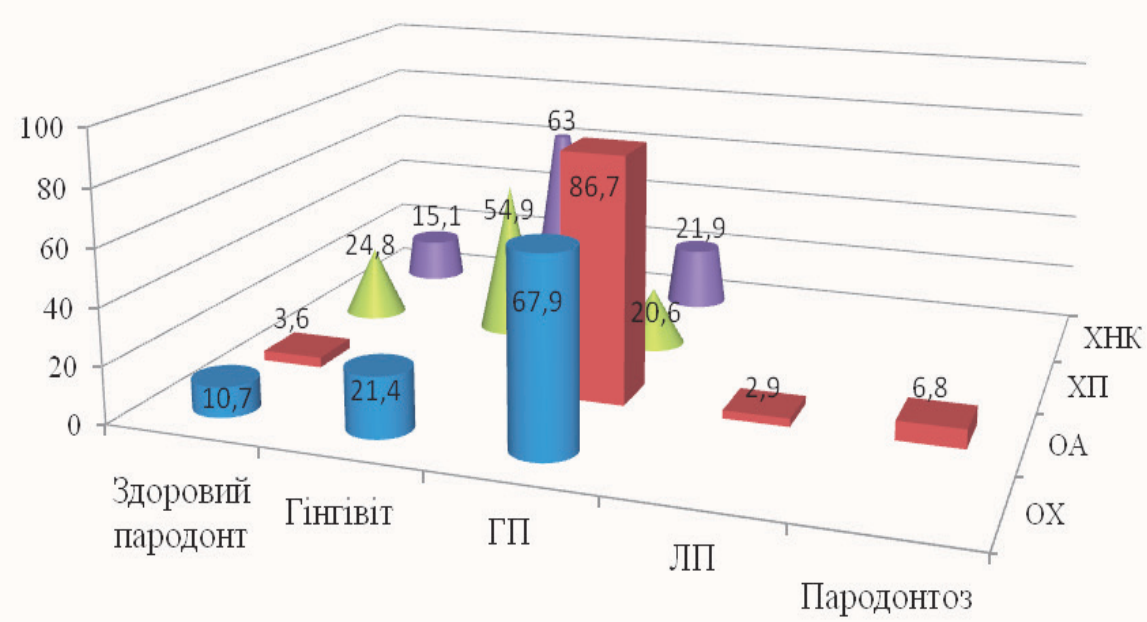

Puc. 1. Діагностична структура захворювань пародонта в групах спостереження.

При збиранні стоматологічного анамнезу обстежені пацієнти 3 опіковою хворобою скаржилися на кровоточивість та набряк ясен, зміщення та рухомість зубів, неприємний запах із порожнини рота, що характерно для клінічної картини захворювань пародонта. Особливу увагу привертає значний рівень загострення дистрофічно-запального процесу в тканинах пародонта у пацієнтів з опіковою хворобою. Скарги на наявну постійну чи тимчасову (при розмові) сухість у порожнині рота пред’являла незначна кількість обстежених пацієнтів [1].

Проведене клінічне обстеження показало, що у хворих на остеоартроз у 246 (92,1 \%) виявлено хронічний перебіг генералізованого пародонтиту. 3 результатів об'єктивного обстеження тканин пародонта хворих на ОА виявило явища симптоматичного хронічного катарального гінгівіту, найчастіше у ділянці нижніх фронтальних зубів - ясна застійно гіперемійовані, з вираженою рецесією ясен, яка проявлялась оголенням поверхонь коренів зубів, ії рівень корелював зі ступенем тяжкості генералізованого пародонтиту [5].

Огляд пацієнтів із хронічними колітами проводили в стаціонарі на 6-10 день їх перебування. У всіх пацієнтів основної групи реєстрували загострення хронічного катарального гінгівіту та генералізованого пародонтиту. Основними скаргами були болючість, припухлість, кровоточивість ясен при чищенні зубів, споживанні їжі та механічному подразненні. Проба Шиллера-Писарєва була різко позитивною як при гінгівітах, так i при пародонтитах. При огляді ясна різкогі- перемійовані, набряклі, болючі при пальпації, кровоточиві при зондуванні, спостерігали ясенні кишені, реєстрували кровоточивість I i II ступенів залежно від діагнозу. В усіх пацієнтів відзначали наявність твердих та м'яких зубних відкладень [9].

У хворих на хронічний панкреатит генералізований катаральний гінгівіт мав хронічний перебіг із періодичними загостреннями у весняно-осінній період та в період загострення ХП. Хворі на хронічний генералізований катаральний гінгівіт пред’являли скарги на свербіж ясен, їх кровоточивість, незначну болючість. При об'єктивному обстеженні у цих пацієнтів відзначали набряклість ясенних сосочків і гіперемію маргінальних ясен без порушення цілості зубоясенного з'єднання, діагностували I ступінь кровоточивості ясен. У всіх хворих виявлено над’ясенні зубні відкладення. При обстеженні хворих на генералізований пародонтит виявляли ціанотичну і нерідко гіперемовану, набряклу в ділянках запалення слизову оболонку ясен, визначали пародонтальні кишені глибиною 2-4 мм, кровоточивість ясен I-II ступенів [13].

Результати огляду ротової порожнини у групах спостереження показали низький рівень догляду за порожниною рота майже у всіх обстежених. Усіпацієнтикористувалисьіндивідуальними засобами догляду за порожниною рота, проте не у всіх випадках була правильно підібрана зубна паста чи щітка, або ж термін користування щіткою значно перевищував рекомендовані. Лише декілька пацієнтів, переважно молодого віку, були обізнані з зубними нитками та ополіскувачами. 
Аналіз показників гігієнічних індексів показав такі результати: значення індексу Федорова-Володкіної у пацієнтів з опіковою хворобою становив $(2,61 \pm 0,21)$ бала - «погано", у хворих на остеоартроз - $(2,14 \pm 0,04)$ бала «задовільно», у хворих на хронічні коліти $(1,92 \pm 0,06)$ бала - «задовільно», у хворих на хронічний панкреатит - $(2,31 \pm 0,07)$ бала «незадовільно» (рис. 2).

Значення індексу Гріна-Вермільйона представило такі показники: у пацієнтів з опіковою хворобою цей індекс дорівнював $(2,62 \pm 0,08)$ бала, у хворих на остеоартроз - $(1,53 \pm 0,04)$ бала, у пацієнтів із хронічними колітами - $(1,39 \pm 0,07)$ бала, у хворих на хронічний панкреатит $(1,78 \pm 0,06)$ бала (рис. 2$)$.

Аналізуючи показники гігієнічних індексів, можна відзначити низький рівень гігієни у всіх групах спостереження, проте найвищі показники були у пацієнтів 3 опіковою хворобою, що пояснюємо тяжким загальним станом пацієнтів, а також загостренням запального процесу в тканинах пародонта, пацієнти фізично не спроможні були проводити необхідні гігієнічні заходи у порожнині рота.

Кількісну оцінку проявів запалення тканин пародонта у групах спостереження було проведено за допомогою папілярно-маргінальноальвеолярного індексу (ПМА).

Середнє значення індексу ПМА у пацієнтів 3 опіковою хворобою складало $(31,82 \pm 0,38) \%$, зокрема індекс ПМА в межах до 25 \% виявлено у 38 (37,2 \%) обстежених пацієнтів, у межах $25-50 \%$ був у 59 (57,3\%), більше $51 \%$ виявлено у 16 (15,5 \%) обстежених пацієнтів.

У хворих на ОА середнє значення індексу ПМА становило $(34,1 \pm 0,8) \%$, зокрема, при ГП початкового - I ступеня тяжкості $(23,8 \pm 1,6) \%$, при ГП II ступеня тяжкості $(33,4 \pm 1,1) \%$, при ГП II-III ступенів тяжкості $(38,7 \pm 1,1) \%$ [6].

Показники індексу ПМА у хворих на хронічні коліти були такими: при хронічному катаральному гінгівіті I ступеня - $(17,0 \pm 0,4) \%$, при гінгівіті II ступеня - $(29,3 \pm 0,9) \%$, а при гінгівіті III ступеня - $51 \%$. Генералізований пародонтит характеризувався такими даними: ГП початкового ступеня - $61 \%$, ГП І ступеня - $(67,7 \pm 1,3) \%$ та ГП II ступеня - $75 \%$ [8].

У хворих на хронічний панкреатит із патологією пародонта індекс ПМА становив $(37,4 \pm 8,8) \%$, що вказує на середній ступінь запалення, при катаральному гінгівіті цей показник дорівнював $(21,3 \pm 2,7) \%$, при генералізованому пародонтиті початкового - I ступеня тяжкості - $(39,2 \pm 2,7) \%$, при генералізованому пародонтиті II ступеня - $(51,7 \pm 1,4) \%$ [12].

Для визначення пародонтологічного статусу користувались ще одним індексом, а саме КПІ (комплексним пародонтальним індексом), за допомогою якого визначали наявність зубних відкладень, пародонтальних кишень, кровоточивість ясен та рухомість зубів і, відповідно, за цим показником встановлювали ступінь тяжкості захворювань пародонта.

При визначенні комплексного пародонтального індексу в жінок з опіковою хворобою встановлено такі запально-деструктивні процеси в тканинах пародонта: у жінок віком $0-18$ років значення індексу КПІ було $(0,03 \pm 0,01)$ бала, у жінок віком 18-29 років - $(0,95 \pm 0,02)$ бала, віком від 30 до 44 років - $(2,13 \pm 0,03)$ бала, віком 45-59 років - $(1,87 \pm 0,03)$ бала.

При визначенні комплексного пародонтального індексу в чоловіків, хворих на опікову хворобу, встановлено такі запальнодеструктивні процеси в тканинах пародонта:

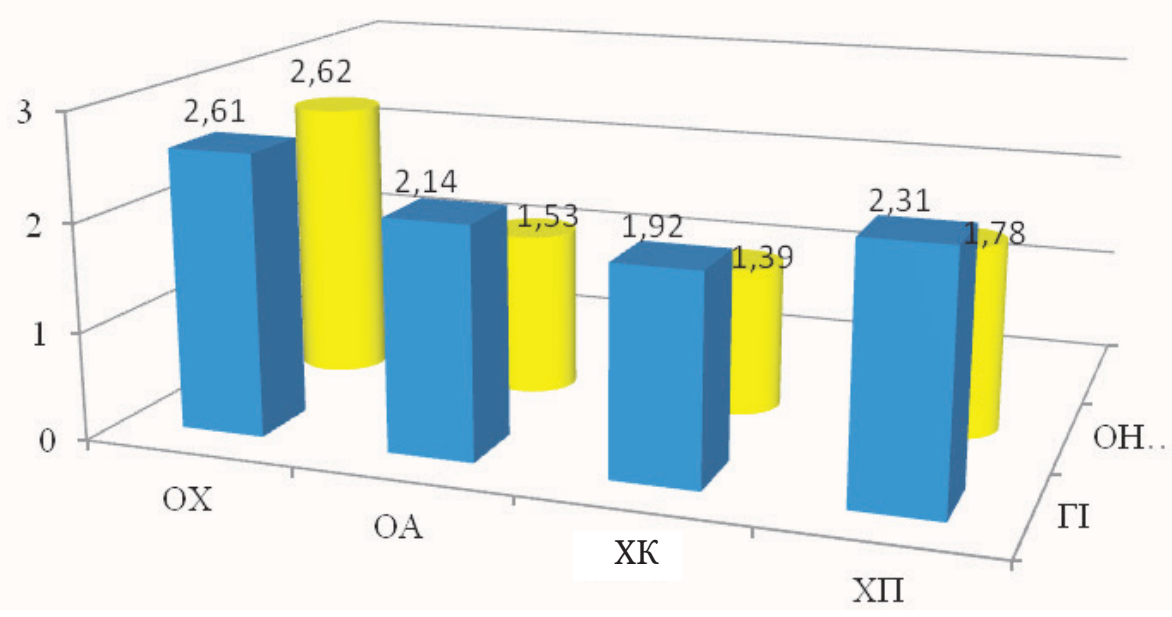

Puc. 2. Графічне зображення гігієнічних індексів у групах спостереження. 
у чоловіків віком 18-29 років - $(1,89 \pm 0,14)$ бала, віком від 30 до 44 років - $(2,18 \pm 0,24)$ бала, віком $45-59$ - $(2,45 \pm 0,08)$ бала. Рівень запалення зростав із поглибленням дистрофічно-запального процесу в тканинах пародонта.

У пацієнтів із хронічними колітами та патологією пародонта показники індексу КПІ були такими: при хронічному катаральному гінгівіті І ступеня - $(1,61 \pm 0,08)$ бала, що відповідає легкому ступеню захворювання, при ГП II ступеня - $(2,54 \pm 0,07)$ бала (середній ступінь захворювання), а при III ступені - 2,61 бала (середній ступінь захворювання). Генералізований пародонтит характеризувався такими показниками: ГП початкового ступеня 3,02 бала (середній ступінь захворювання), ГП I ступеня - $(3,09 \pm 0,05)$ бала (середній ступінь захворювання) та ГП II ступеня - 3,71 бала (тяжкий ступінь захворювання). У загальному у хворих на ХК індекс КПІ склав $(2,2 \pm 1,31)$ бала і відповідає середньому ступеню тяжкості захворювання [8].

У хворих на хронічний панкреатит із супутнім катаральним гінгівітом індекс КПІ дорівнював $(1,43 \pm 0,06)$ бала, при ГП І ступеня тяжкості - $(1,6 \pm 0,1)$ бала, при ГП II ступеня тяжкості - $(4,48 \pm 0,12)$ бала, середнє значення КПІ становило $(2,5 \pm 0,9)$ бала, що відповідає середньому ступеню ураження тканин пародонта [12].

У хворих на ОА КПІ був найвищим і становив у середньому $(4,37 \pm 0,04)$ бала, що відповідає тяжкому ступеню ураження тканин пародонта. При ГП І ступеня тяжкості КПІ дорівнював $(3,45 \pm 0,09)$ бала, що відповідає середньому ступеню ураження, при ГП II ступеня $(4,21 \pm 0,04)$ бала та при ГП II-III ступенів тяжкості - $(4,88 \pm 0,03)$ бала, що свідчить про тяжкий рівень захворювання тканин пародонта.

\section{Список літератури}

1. Бойцанюк С. І. Особливості перебігу та лікування захворюваньпародонтаухворихна опіковухворобу: автореф. дис. на здобуття наук. ступеня канд. мед. наук [спец.] 14.01.22 «Стоматологія» / С. І. Бойцанюк // Укр. мед. стомат. акад. - Полтава, 2013. - 20 с.

2. Бойцанюк С. I. Поширеність та структура захворювань пародонта у хворих на опікову хворобу / C. I. Бойцанюк // Інноваційні технології в стоматології : наук.-практ. конф., 2011. - Тернопіль, 2011. C. 76-77.

3. Гончарук Л. В. Взаимосвязь воспалительных заболеваний пародонта и соматической патологии / Л. В. Гончарук, К. Н. Косенко, С. Ф. Гончарук // Современная стоматология. - 2010. - № 1. - С. 37-40.
Висновки. 1. Виявлено високу поширеність захворювань пародонта у пацієнтів із різною супутньою патологією: у пацієнтів з опіковою хворобою - 89,32 \%, у хворих на остеоартроз $96,43 \%$, в пацієнтів із хронічними колітами $84,93 \%$, у хворих на хронічний панкреатит $75,49 \%$.

2. Діагностична структура захворювань пародонта у пацієнтів 3 опіковою хворобою та остеоартрозом характеризувалась переважанням деструктивно-запальних захворювань пародонта (генералізований пародонтит) - 67,9 та 86,7 \% відповідно, а у хворих на хронічні коліт та панкреатит - запальних захворювань пародонта (гінгівіт) - 63,0 та 54,9 \% відповідно.

3. У пацієнтів з опіковою хворобою особливу увагу привертає значний рівень загострення дистрофічно-запального процесу в тканинах пародонта, наявні скарги на сухість слизової оболонки ротової порожнини.

4. В осіб, хворих на ОА, переважають хронічний генералізований пародонтит, помірно виражені явища запального процесу м'яких тканин ясен при значній резорбції кісткової тканини альвеолярного відростка, індекс КП $-4,37 \pm 0,04$.

5. У всіх хворих на хронічні коліти реєстрували загострення хронічного катарального гінгівіту та генералізованого пародонтиту, проба Шиллера-Писарєва була різко позитивною, ясна гіперемійовані, набряклі, болючі при пальпації, кровоточиві при зондуванні, наявні ясенні кишені, індекс КПІ $(2,2 \pm 1,31)$ бала.

6. У пацієнтів із хронічним панкреатитом захворювання пародонта характеризувались хронічним перебігом із періодичними загостреннями у весняно-осінній період та у період загострення хронічного панкреатиту, індекс ПМА - $(37,4 \pm 8,8) \%$, індекс КПІ - $(2,5 \pm 0,9)$ бала.

4. Заболотний Т. Д. Запальні захворювання пародонта / Т. Д. Заболотний, А. В. Борисенко, Т. І. Пупін. - Львів : ГалДент, 2013. - 233 с.

5. Залізняк М. С. Особливості лікування захворювань пародонта в умовах курортної реабілітації хворих на остеоартроз : автореф. дис. на здобуття наук. ступеня канд. мед. наук [спец.] 14.01.22 «Стоматологія» / М. С. Залізняк, Львівський національний медичний університет імені Данила Галицького. - Львів, 2012. - 19 с.

6. Залізняк М. С. Пародонтальний статус хворих на остеоартроз / М. С. Залізняк // Український стоматологічний альманах. - 2014. - № 2. - С. 16-18.

7. Зв'язок захворювань пародонта із загальносоматичною патологією / О. М. Немеш, 3. М. Гонта, 
I. В. Шилівський, А. П. Скалат // Новини стоматології. - 2006. - № 2. - С. 34-37.

8. Манащук Н. В. Клінічна ефективність комбінованого застосування антисептика та імуномодулятора при лікуванні захворювань пародонта у хворих 3 хронічними колітами різної етіології : автореф. дис. на здобуття наук. ступеня канд. мед. наук: [спец.] 14.01.28 «Клінічна фармакологія» / Н. В. Манащук, Одеський національний медичний університет. Одеса, 2012. - 19 с.

9. Манащук Н. В. Розповсюдженість та клінічний перебіг захворювань пародонта на тлі хронічних колітів / Н. В. Манащук // Вісник проблем біології і медицини. - 2014. - Вип. 2, т. 1 (107). - С. 239-242.

10. Нигматов Р. Н. Состояние костной ткани пародонта у больных с заболеваниями внутренних органов / Р. Н. Нигматов, Н. Юлдашева, Н. Р. Нигматова // Вісник стоматології. - 2008. - № 2. - С. 58-62.
11. Терапевтична стоматологія. Том 3. Захворювання пародонта / [Н. Ф. Данилевський, А. В. Борисенко, А. М. Політун та ін.]. - К. : Медицина, 2008. - 614 с. 12. Чорній Н. В. Клінічне обгрунтування комбінованого застосування орального антисептика та гепатопротектора для лікування захворювань пародонта на тлі хронічного панкреатиту : автореф. дис. на здобуття наук. ступеня канд. мед. наук [спец.] 14.01.28 «Клінічна фармакологія» / Н.В.Чорній, Одеський національний медичний університет. Одеса, 2012. - 20 с.

13. Чорній Н. В. Розповсюдженість та особливості клінічних проявів захворювань тканин пародонта у хворих на хронічний панкреатит / Н. В. Чорній // Буковинський медичний вісник. - 2014. - Т. 18, № 2(70). - С. 116-118. 